\title{
Amostra isolada de urina para avaliação de proteinúria no Lúpus Eritematoso Sistêmico
}

Paulo Roberto Donadio; Sérgio Seiji Yamada; Emerson Barili; Fernada Maria Borghi; Juliana Yuri Sekiyama;
Pedro Henrique Pelissari; Lorena Bossoni Miosso Marchiotti; Sueny de Paula Munarin Sanches.
Universidade Estadual de Maringá - Hospital Universitário Regional de Maringá - Paraná.

Introdução: O Lúpus Eritematoso Sistêmico (LES) é uma doença inflamatória crônica autoimune, cuja etiopatogenia envolve múltiplos genes, fatores hormonais e ambientais. Uma das mais sérias complicações do LES é a nefrite lúpica (NL), sendo definidora de mal prognóstico. A quantificação da proteinúria é um teste de grande valor no acompanhamento da NL, constituindo-se em marcador diagnóstico e de prognóstico, além de ser fundamental para avaliação da resposta clínica ao tratamento. O padrão ouro atual é a determinação da proteinúria na urina de 24 horas (P24h), porém há algumas dificuldades, como aderência do paciente a uma coleta adequada, e o manuseio desse material em laboratórios.

Objetivos: Avaliar a possibilidade de utilização da relação proteína/creatinina $(\mathrm{P} / \mathrm{C})$ em amostra isolada urinária como alternativa para acompanhamento dos pacientes com NL.

Método: Estudo analítico observacional comparando a P/C e P24h de 77 pacientes com LES acompanhados durante o ano de 2019, em um ambulatório especializado de um hospital universitário, sendo 34 pacientes com NL e 43 sem esta manifestação.

\begin{tabular}{ccc} 
& $\begin{array}{c}\text { Nefrite Lúpica } \\
34 \text { pacientes }\end{array}$ & $\begin{array}{r}\text { LES sem nefrite } \\
\text { Idade }\end{array}$ \\
\hline Sexo feminino & $38 \pm 12,44$ & $41,42 \pm 14,17$ \\
\hline P24h (mg) & $913 \pm 109 \%)$ & $39(90 \%)$ \\
\hline P/C & $0,719 \pm 0,962$ & $0,261 \pm 0,374$
\end{tabular}

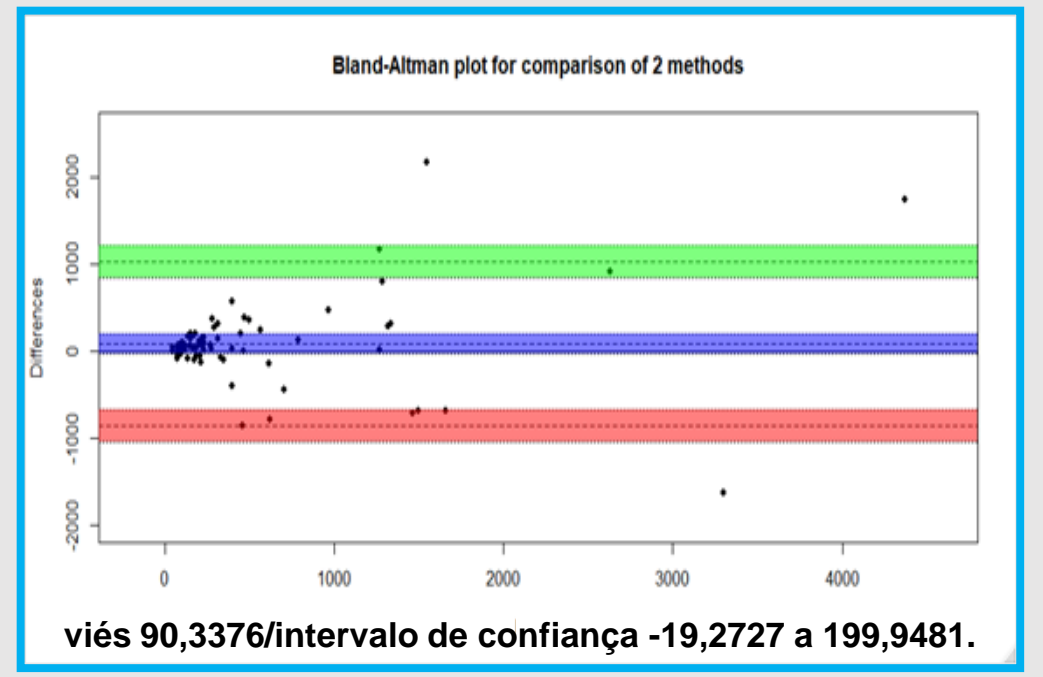

Resultados: Foi realizada a análise de todo o conjunto de dados de quantificação de $\mathrm{P} 24 \mathrm{~h}$ em relação à $\mathrm{P} / \mathrm{C}$, levando em consideração a totalidade de pacientes participantes do estudo, o que demonstrou forte correlação ( $r$ 0,8117), assim como nos pacientes sem lesão renal ( $r$ 0,7689) e NL ( $r$ 0,7969). Para investigar o grau de equivalência de concordância entre os dois métodos, adotamos a interpretação de dois testes: coeficiente de concordância de Lin (CCL) e procedimento de Bland-Altman plot (BAP). Desse modo, com uma estimativa de 0,8006 no CCL, e um viés elevado (90,3376, com intervalo de confiança [-19.2727; 199.9481]) no BAP, verificase que não existe concordância entre os procedimentos.

Conclusão: A partir destes resultados não é possível a substituição do teste padrão ouro (P24h), pela razão $\mathrm{P} / \mathrm{C}$, devido à baixa concordância, apesar da alta correlação. Desta forma, embora possa ser utilizada a $\mathrm{P} / \mathrm{C}$ como estimativa da proteinúria, não é possível a substituição do padrão ouro de P24h por P/C durante as avaliações seriadas de acompanhamento terapêutico.

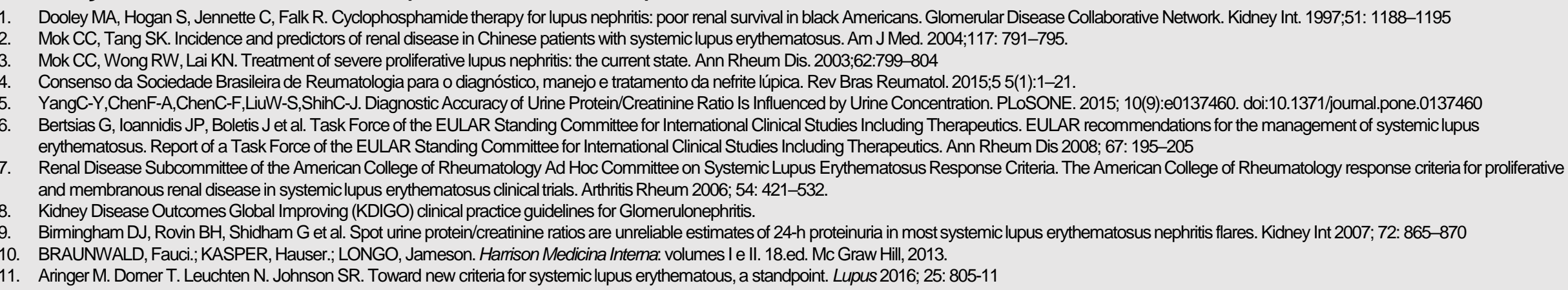

